\title{
Don't forget 'simple' causes of abdominal pain
}

\author{
Valentina Giorgio, Serena Monaco, Roberta Onesimo, Carlo Fundarò \\ Department of Pediatrics, Catholic University of Sacred Heart, Rome, Italy
}

Correspondence to Dr Roberta Onesimo,roberta_onesimo@yahoo.it

\section{DESCRIPTION}

A 6-year-old male child presented with intermittent abdominal pain and alternating bowel since 1 year. Lab tests resulted negative, except for high erythrocyte sedimentation rate. Stool studies-occult blood and microbiologyresulted unremarkable. Symptoms were persistent and started impairing the child's life everyday. Despite failure to thrive, abdominal pain at night was not registered. Abdomen ultrasound showed thickening of distal ileum, and mildly enlarged mesenteric lymph nodes. At lower endoscopy in the distal ileum worms crawling on the wall were seen (see Video 1). Direct microscopy showed Enterobius vermicularis (EV). Random biopsies of the colon revealed lymph-node hyperplasia. The patient was twice successfully treated with mebendazole (200 mg/day).

$\mathrm{EV}$ - pinworm - is the most common helminthes infection in Western Europe and North America. ${ }^{1}$ The infestation occurs worldwide, affecting all socioeconomic groups, particularly school-aged children. The interhuman transmission is oro-faecal. Most patients are asymptomatic, and when symptoms are present, peri-anal itchingespecially at night-is the most common clinical feature.

The child came to our observation after first-line investigations. Stool exams (microbiology+scotch-test) should have been repeated before performing lower endoscopy as indicated for abdominal pain with 'red-flags', ${ }^{2}$ such as in the suspicion of inflammatory bowel diseases (IBDs). Infectious diseases must be strongly excluded before thinking of inflammatory ones. With the improvement in scientific knowledge and in diagnostic accuracy, it is easy to focus the attention on major diseases despite minor ones. In our case we performed endoscopy in the suspicion of IBDs (prevalence $0.6 \%)^{3}$ but diagnosed parasitosis (prevalence $30-40 \%)^{1}$

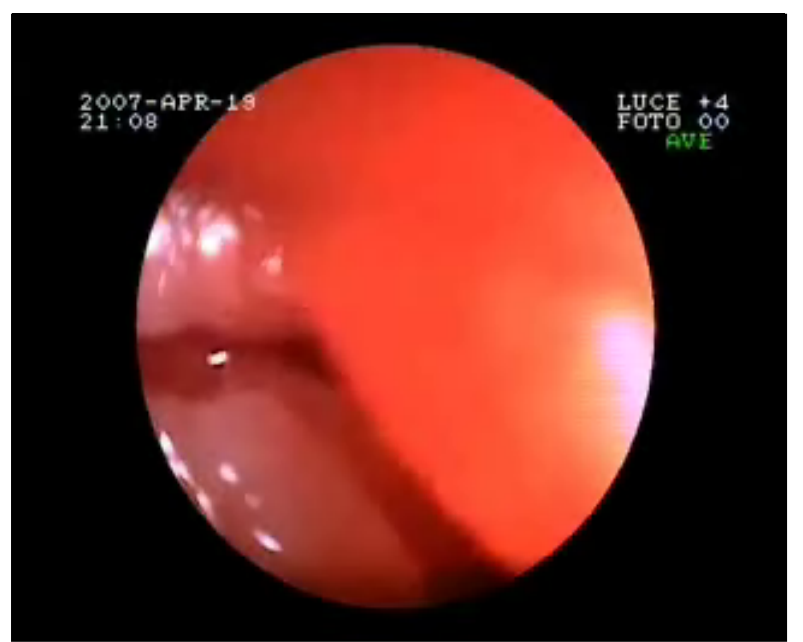

Video 1 Lower endoscopy revealed pinworm crawling on the wall of the distal ileum.

Competing interests None

Patient consent Obtained.

\section{REFERENCES}

1. Piperaki ET, Spanakos G, Patsantara G, et al. Characterization of Enterobius vermicularis in a human population, employing a molecular-based method from adhesive tape samples. Mol Cell Probes 2011;25:121-5.

2. Noe JD, Li BU. Navigating recurrent abdominal pain through clinical clues, red flags, and initial testing. Pediatr Ann 2009;38:259-66.

3. Molodecky NA, Soon IS, Rabi DM, et al. Increasing incidence and prevalence of the inflammatory bowel diseases with time, based on systematic review. Gastroenterology 2012;142:46-54. 


\section{BMJ Case Reports}

This pdf has been created automatically from the final edited text and images.

Copyright 2012 BMJ Publishing Group. All rights reserved. For permission to reuse any of this content visit http://group.bmj.com/group/rights-licensing/permissions.

BMJ Case Report Fellows may re-use this article for personal use and teaching without any further permission.

Please cite this article as follows (you will need to access the article online to obtain the date of publication).

Giorgio V, Monaco S, Onesimo R, Fundarò C. Don't forget 'simple' causes of abdominal pain. BMJ Case Reports 2012;10.1136/bcr-2012-006502, Published XXX

Become a Fellow of BMJ Case Reports today and you can:

- Submit as many cases as you like

- Enjoy fast sympathetic peer review and rapid publication of accepted articles

- Access all the published articles

- Re-use any of the published material for personal use and teaching without further permission

For information on Institutional Fellowships contact consortiasales@bmjgroup.com

Visit casereports.bmj.com for more articles like this and to become a Fellow 